\title{
Penelitian STUDI PENAMBATAN MOLEKULER DAN PREDIKSI ADMET SENYAWA BIOAKTIF BEBERAPA JAMU INDONESIA TERHADAP SARS-COV-2 MAIN PROTEASE (M ${ }^{\text {pro })}$
}

\author{
Sheniez Adhitya Yasin ${ }^{1}$, Alya Azzahra ${ }^{1}$, Norman Emil \\ Ramadhan ${ }^{1}$, Vega Mylanda ${ }^{1}$ \\ ${ }^{1}$ Fakultas Farmasi, Universitas Indonesia, Depok, Indonesia \\ Corresponding authors's email: alya5499@gmail.com
}

\begin{abstract}
ABSTRAK
Coronavirus jenis baru SARS-CoV-2 telah menyebabkan penyakit pandemi global terbesar pada tahun 2020 yang dikenal dengan Coronavirus Disease-2019 (COVID-19). Terapi potensial untuk penyakit ini masih terus diteliti, termasuk dari senyawa alami. Jamu merupakan obat tradisional yang berasal dari tumbuhan herbal Indonesia dan memiliki berbagai khasiat. Penelitian ini dilakukan dengan tujuan untuk menemukan potensi jamu Indonesia dalam terapi COVID-19. Sebanyak 283 senyawa bioaktif dari jamu Indonesia disaring melalui penapisan berdasarkan parameter Lipinski's Rule of Five dan prediksi ADMET (Absorpsi, Distribusi, Metabolisme, Eksreksi, dan Toksisitas) menggunakan ProTox-II dan SwissADME. Sebanyak 12 senyawa hasil penapisan kemudian dilanjutkan untuk diuji melalui penambatan molekuler terhadap SARS-CoV-2 Main Protease (Mro) menggunakan AutoDock Vina. Hasil penelitian ini menunjukkan bahwa Kurkuminol D memiliki energi bebas ikatan $(\Delta \mathrm{G})$; sebesar $-6,9 \mathrm{kkal} / \mathrm{mol}$; dan konstanta inhibisi (Ki); sebesar 2,99 $\mu \mathrm{M}$; terendah dibandingkan senyawa hasil penapisan lainnya. Namun, tidak ada senyawa hasil penapisan yang memiliki $\Delta G$ lebih rendah daripada $\Delta G$ kedua kontrol positif, yaitu sebesar $-8,2 \mathrm{kkal} / \mathrm{mol}$ (Lopinavir) dan $-7,8 \mathrm{kkal} / \mathrm{mol}$ (Ritonavir). Potensi inhibisi SARS-CoV-2 oleh Kurkuminol $D$ dari penelitian ini dapat menjadi titik awal dalam proses pengembangan obat terapi COVID-19 dari senyawa alami.
\end{abstract}

Kata kunci: ADMET, COVID-19, jamu, penambatan molekuler, SARS-CoV-2

\begin{abstract}
The novel coronavirus SARS-CoV-2 has caused the biggest global pandemic disease in 2020 known as Coronavirus Disease-2019 (COVID-19). Current studies are still trying to find potential therapies of the disease, including from natural compounds. Jamu is traditional medicine from herbs in Indonesia that possesses some medicinal properties. This research was done to find and explore the potential of Indonesian jamus as novel COVID-19 treatment. 283 bioactive compounds from Indonesian jamus were screened with ADMET (Absorption, Distribution, Metabolism, Excretion, and Toxicity) predictions and Lipinski's Rule of Five parameters using ProTox-Il and SwissADME. The 12 screened compounds then continued to be tested through molecular docking against SARS-CoV-2 Main Protease ( $M^{\text {pro }}$ ) using AutoDock Vina. The result of our study showed that Curcuminol $D$ has the lowest binding free energy of $-6.9 \mathrm{kcal} / \mathrm{mol}$ and $\mathrm{Ki}$ (inhibition constant) of 2.99 $\mu M$ compared to the other screened compounds. However, none of the screened compounds has lower binding free energy than the positive controls', which valued -8.2 $\mathrm{kcal} / \mathrm{mol}$ (Lopinavir) and $-7.8 \mathrm{kcal} / \mathrm{mol}$ (Ritonavir). The potential inhibition of SARS-CoV-2 by Curcuminol $D$ from this study could be a starting point in the drug discovery process from natural compounds for treating COVID-19.
\end{abstract}

Keywords: ADMET, COVID-19, jamu, molecular docking, SARS-CoV-2

\section{PENDAHULUAN}

Coronavirus

disease-2019

(COVID-19), yang disebabkan oleh

infeksi dari severe acute respiratory syndrome coronavirus 2 (SARS-CoV-2), merupakan penyakit pernapasan yang awalnya diidentifikasi di Wuhan, China, pada Desember 2019. World Health 
Organization (WHO) menyatakan COVID-19 sebagai pandemi pada 11 Maret 2020 (Kementerian Kesehatan Republik Indonesia, 2020). COVID-19 menyebar dengan cepat melalui transmisi kontak, aerosol, dan droplet (Michele et al., 2020). Sebagai negara dengan kasus COVID-19 tertinggi di Asia Tenggara, Indonesia telah mencapai 177.571 kasus dan 7.505 kematian akibat COVID-19 dengan case fatality rate (CFR) sebesar 4,2\% pada 1 September 2020 (Worldometer, 2020). Jumlah kematian yang terus meningkat menyebabkan gangguan dalam sistem kesehatan dan juga mempengaruhi sektor lain, seperti ekonomi dan sosial (WHO, 2020).

Suatu systematic review yang dilakukan oleh Zhang \& Liu (2020) menunjukkan bahwa kombinasi Ribavirin dan interferon- $\beta$ dapat menjadi terapi yang menjanjikan sebagai agen penghambat replikasi SARS-CoV-2 (Alanagreh et al. (2020); Zhang \& Liu, 2020). Namun, studi in vivo oleh Booth et al. (2003) dan studi in vitro oleh Tan et al. (2004) tidak menganjurkan penggunaan kombinasi tersebut akibat adanya aktivitas hemolisis dan tidak memiliki aktivitas yang signifikan terhadap virus tersebut (Alanagreh et al., 2020; Booth et al., 2003; Tan et al., 2004). Selain itu, penggunaan Favipiravir, Remdevisir, dan Hidroklorokuin juga tidak menunjukkan efikasi yang cukup terhadap COVID-19 (Jomah et al., 2020; Principi \& Esposito, 2020; WHO, 2020). Oleh karena itu, pengembangan obat baru yang berpotensial dalam menangani COVID19 perlu dilakukan. Salah satu cara dalam mengembangkan obat baru adalah melalui tumbuhan medisinal.

$$
\text { Indonesia memiliki } \quad 30.000
$$

spesies tumbuhan medisinal atau sekitar $80 \%$ dari tumbuhan medisinal di seluruh dunia. Sekitar 6.000 tumbuhan memiliki berbagai aktivitas biologis dan 1.000 spesies umumnya digunakan sebagai jamu (Widyowati \& Agil, 2018; Elfahmi et al., 2014). Jamu merupakan obat herbal asli Indonesia yang telah digunakan secara empiris untuk menjaga kesehatan dan menangani berbagai penyakit (Kartini et al., 2019). Cina dan Korea Selatan telah menggunakan obat tradisional sebagai pedoman pencegahan dan terapi COVID-19 (Ang et al., 2020). Penelitian sebelumnya menunjukkan bahwa Phyllanthus niruri atau disebut dengan Meniran memiliki potensi inhibisi terhadap herpes simplex virus (HSV), hepatitis $B$ virus (HBV), hepatitis $C$ virus (HCV), dan immunodeficiency virus (HIV) manusia (Forero et al., 2008; Tan et al., 2013; Wahyuni et al., 2019).

SARS-CoV-2 main protease $\left(\mathrm{M}^{\text {pro }}\right)$ atau 3-chymotrypsin-like proteae $\left(3 \mathrm{CL}^{\text {pro }}\right)$ merupakan salah satu target obat terbaik dalam aksi farmakologis antiviral terhadap COVID-19 (Estrada, 2020; Qamar et al., 2020). Inhibisi enzim ini akan menghentikan replikasi virus SARS-CoV-2 (Khaerunnisa et al., 2020; 
Ulrich \& Nitsche, 2020). Beberapa inhibitor protease telah dikembangkan untuk menghentikan penyebaran virus yang menyebabkan penyakit HIV-AIDS, MERS, dan SARS (Zumla et al., 2020). Namun, belum ada studi yang menguji jamu sebagai terapi COVID-19 melalui inhibisi M ${ }^{\text {pro }}$ SARS-CoV-2.

Tahap awal dari pengembangan obat dapat dilakukan dengan metode penambatan molekuler dan prediksi Absorpsi, Distribusi, Metabolisme, Eksreksi, dan Toksisitas (ADMET). Penambatan molekuler merupakan metode untuk menganalisis interaksi antara senyawa kandidat obat dan target protein sehingga dapat memprediksi aktivitas atau inhibisi suatu enzim (Dar \& Mir, 2017; Torres et al., 2019). Selain itu, keberhasilan suatu pengembangan obat ditentukan oleh profil ADMET yang baik, karena kegagalan yang berhubungan dengan farmakokinetik kerap terjadi pada uji klinis (Moroy et al., 2012).

\section{METODE}

\subsection{Seleksi Senyawa Berdasarkan Prediksi ADMET}

Sebanyak 283 senyawa bioaktif dari jamu yang biasa digunakan didapat dari penelitian sebelumnya dari Widyowati dan Agil pada tahun 2018 (Widyowati \& Agil, 2018). SMILES senyawa bioaktif tersebut diambil dari pangkalan data PubChem (https://pubchem.ncbi.nlm.nih.gov/) untuk disaring dengan prediksi ADMET (Absorpsi, Distribusi, Metabolisme,
Ekskresi, dan Toksisitas) dan parameter Lipinski's rule of five menggunakan ProTox-II (http://bioinfapache.charite.de/main/index. php) dan SwissADME (http://www.swissadme.ch/) (Banerjee, Eckert, Schrey \& Preissner, 28; Daina, Michielin, \& Zoete, 2017).

Seleksi prediksi ADMET dilakukan untuk menentukan kandidat obat yang tidak beracun dan memiliki profil farmakokinetik oral yang baik ditentukan oleh parameter berikut; penyerapan Gl tinggi, skor bioavailabilitas 0.55 , dikelompokkan dalam toksisitas kelas VI LD50 (lebih dari $5,000 \mathrm{mg} / \mathrm{kg}$ ), non-karsinogenik, dan non-mutagenik (Daina, Michielin, \& Zoete, 2017; Martin, 2005).

Sementara itu, Lipinski's rule of five digunakan untuk mengevaluasi kemiripan senyawa dengan karakteristik obat oral yang memiliki aktivitas biologis pada manusia. Aturan tersebut mengusulkan bahwa molekul harus mematuhi komponen berikut: 1) tidak lebih dari lima donor ikatan hidrogen 2) tidak lebih dari sepuluh akseptor ikatan hidrogen karena tingginya jumlah ikatan hidrogen dapat mengurangi partisi molekul dari fase larut air ke dalam membran bilayer lipid untuk permeasi dengan difusi pasif 3) kurang dari 500 Dalton massa molekul karena massa molekul tinggi mengurangi konsentrasi senyawa pada permukaan epitel usus yang mengurangi penyerapan 4) tidak lebih dari $5 \log \mathrm{P}$ (koefisien partisi oktanol-air), karena nilai logP tinggi 
dapat menyebabkan penyerapan yang

buruk (Lipinski, 2004; Liu dkk, 2019).

\subsection{Preparasi Macromolekul dan Ligan untuk Penambatan Molekuler}

12 ligan terpilih yang memenuhi kriteria tersebut kemudian digambar dengan menggunakan MarvinSketch (ChemAxon, 2018). Struktur 3D senyawa kemudian dioptimasi dengan penambahan medan gaya MMFF94 dan hidrogen polar, sebelum dikonversi ke *format .pdb oleh OpenBabel (O'Boyle et al., 2011).

Struktur kristal makromolekul $\mathrm{M}^{\text {pro }}$ SARS-CoV-2 diambil dari RCSB Protein Data Bank (RCSB PDB, http://www.rcsb.org/) dalam *format .pdb (PDB ID: 6LU7; Resolusi: 2.16 Å) dengan ligan native $\mathrm{n}$-[(5-methylisoxazol3-yl)carbonyl]alanyl-I-valyl-n 1 -((1r,2z)4-(benzyloxy)-4-oxo-1-\{[(3r)-2oxopyrrolidin-3-yl]metil\}but-2-enyl)-Ileucinamide (ID: PRD) (Jin et al., 2020). Makromolekul kemudian dioptimasi dengan menghapus molekul air dan ligan native, menggabungkan hidrogen nonpolar dan penambahan hidrogen polar dan muatan Gasteiger dengan AutoDock Vina.

\subsection{Penambatan dan Analisis Molekuler}

Validasi protokol penambatan molekuler dilakukan dengan men- redocking ligan native ke makromolekul dan diukur dengan nilai RMSD-nya. Koordinat untuk protokol penambatan ini adalah $\mathrm{x}=-9.732, \mathrm{y}=11.403, \mathrm{z}=68.483$. AutoDock Vina digunakan untuk penambatan ligan terhadap makromolekul dengan parameter Lamarckian Genetic Algorithm (LGA) dengan jumlah run 10 kali. AutoDock Vina adalah alat penambatan yang merupakan Autodock generasi berikutnya dan berjalan lebih cepat dengan lebih akurat daripada pendahulunya, AutoDock 4.0 (Trott \& Olson, 2009). Protokol penambatan molekuler dinyatakan valid jika nilai RMSD dari superposisi redocking kurang dari 2 A (Kroemer, 2007).

Parameter yang divariasikan dalam proses validasi adalah ukuran kotak grid (22.5 $\AA$; $26.25 \AA$; $30 \AA$ A $)$ dan exhaustiveness (8 dan 16). Parameter yang memiliki RMSD terendah dipilih sebagai parameter penambatan senyawa uji. Hasil penambatan dievaluasi melalui parameter energi bebas ikatan $(\Delta G)$ dan konstanta inhibisi (Ki). Visualisasi interaksi protein-ligan dianalisis dengan menggunakan LigPlot+ dan PyMOL versi 1.7.4.5 untuk mengamati ikatan hidrogen dan interaksi hidrofobik antara protein dan ligan (Laskowski, \& Swindells, 2011; Delano \& $\mathrm{Ph}, 2004)$. 
3. HASIL

Tabel 1. Hasil Validasi Protokol Penambatan

\begin{tabular}{c} 
Ukuran \\
Exhaustiveness Grid Box RMSD (Å) \\
\hline \\
\hline
\end{tabular}

Gambar 1. Superposisi dari Ligan Native PRD (Hijau) dan Ligan Hasil Redocking (Biru)
Tabel 2. Hasil Penambatan dari Ligan Uji yang diperoleh dari Jamu, Ritonavir, dan Lopinavir

\begin{tabular}{|c|c|c|c|}
\hline No. & Senyawa & $\begin{array}{c}\Delta \mathbf{G} \\
\text { (kkal/ } \\
\text { mol) }\end{array}$ & $\begin{array}{c}\mathbf{K i} \\
(\mu \mathrm{M})\end{array}$ \\
\hline & Ritonavir & $-7,8$ & 0,71 \\
\hline & Lopinavir & $-8,2$ & 0,27 \\
\hline
\end{tabular}

$15 \quad$ Turmerone $A \quad-6,3 \quad 9,04$

$18 \quad$ Turmerone $Q \quad-6,2 \quad 10,87$

76 Dehydro-6-gingerdione $-5,8 \quad 22,73$

82 Dehydrocurdione $\quad-5,9 \quad 18,9$

$85 \quad$ Curcumanolide $A \quad-5,5 \quad 39,52$

$86 \quad$ Curcumanolide $B \quad-5,8 \quad 22,73$

99 15-Hydroxyprocurcumenol $\quad-5,9 \quad 18,9$

101 (E)-Labda-8(17),12-diene- $\quad-5,6 \quad 32,86$ 15,16-dial

$137 \quad$ Curcuminol $D \quad-6,9 \quad 2,99$

165 4-oxo- $\beta$-isodamascol $\quad-4,9 \quad 119,44$

$184 \quad$ zerumbone epoxide $\quad-5,8 \quad 22,73$

212 Ethyl 4-methoxy- $\quad-5,3 \quad 57,14$ transcinnamate 


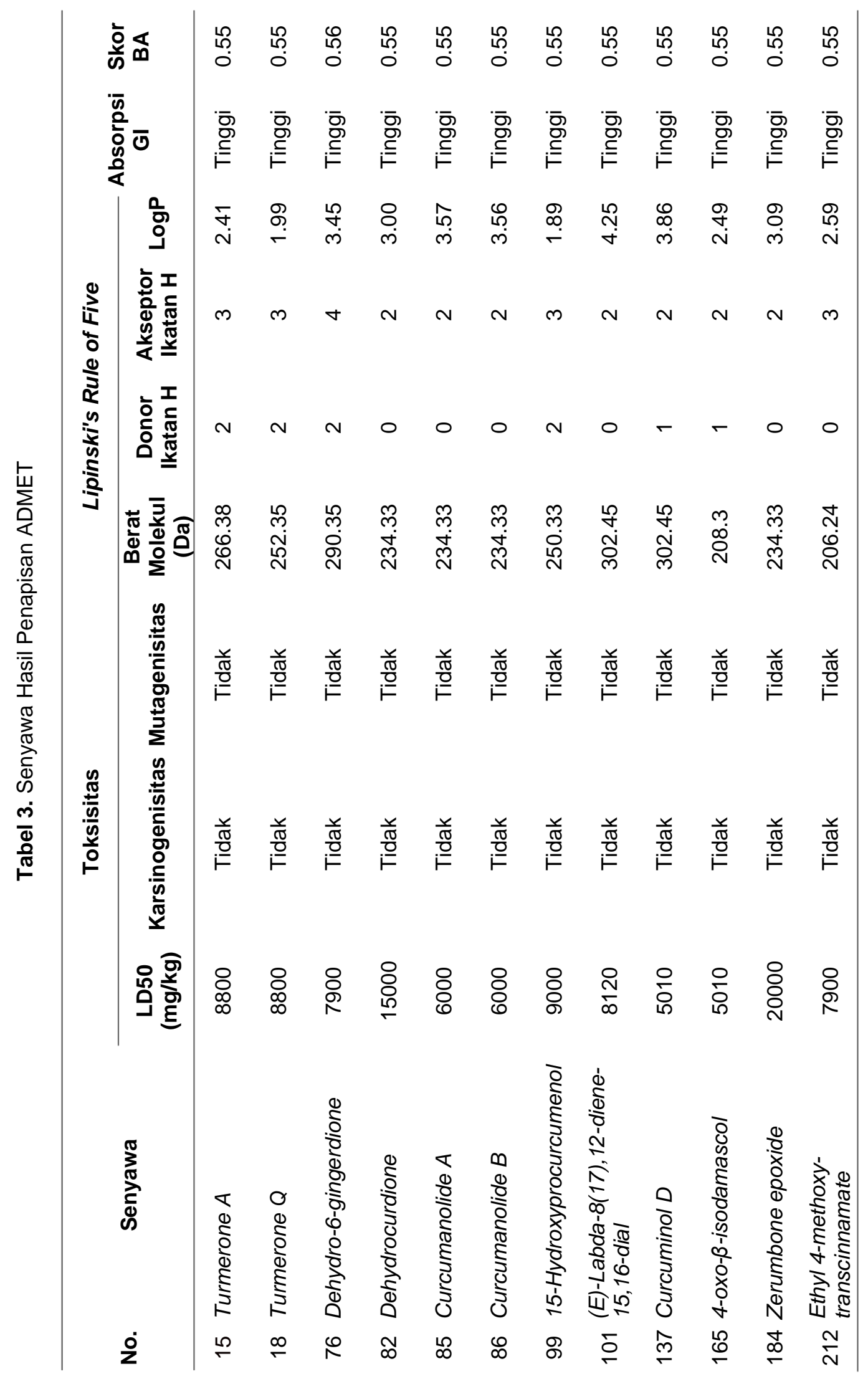


Tabel 4. Hasil Visualisasi Ligan Uji terhadap Mpro SARS-CoV-2

\begin{tabular}{|c|c|c|c|c|c|c|c|c|c|c|c|c|c|c|}
\hline & LPN & RTN & 15 & 18 & 76 & 82 & 85 & 86 & 99 & 101 & 137 & 165 & 184 & 212 \\
\hline Thr24 & $\sqrt{ }$ & $\sqrt{ }$ & & & & & & & & & & & & \\
\hline Thr25 & $\sqrt{ }$ & $\sqrt{ }$ & & & & & & & & & & & & \\
\hline Thr26 & $\sqrt{ }$ & $\sqrt{ }$ & & & & & $\sqrt{ }$ & & & $\sqrt{ }$ & & & & \\
\hline Leu27 & & $\sqrt{ }$ & & & & & $\sqrt{ }$ & & & & & & & \\
\hline His41 & $\sqrt{ }$ & $\sqrt{ }$ & $\sqrt{ }$ & $\sqrt{ }$ & & $\sqrt{ }$ & $\sqrt{ }$ & & $\sqrt{ }$ & & & & & $\sqrt{ }$ \\
\hline Thr45 & & $\sqrt{ }$ & & & & & & & & & & & & \\
\hline Ser46 & & $\sqrt{ }$ & & & & & & & & & & & & \\
\hline Met49 & $\sqrt{ }$ & $\sqrt{ }$ & $\sqrt{ }$ & $\sqrt{ }$ & & $\sqrt{ }$ & $\sqrt{ }$ & & $\sqrt{ }$ & $\sqrt{ }$ & & & $\sqrt{ }$ & $\sqrt{ }$ \\
\hline Tyr54 & & & $\sqrt{ }$ & $\sqrt{ }$ & & & & & & & & & & $\sqrt{ }$ \\
\hline Phe140 & $\sqrt{ }$ & $\sqrt{ }$ & & $\sqrt{ }$ & $\sqrt{ }$ & & & $\sqrt{ }$ & & $\sqrt{ }$ & & & & $\sqrt{ }$ \\
\hline Leu141 & $\sqrt{ }$ & $\sqrt{ }$ & $\sqrt{ }$ & & $\sqrt{ }$ & $\sqrt{ }$ & $\sqrt{ }$ & $\sqrt{ }$ & & $\sqrt{ }$ & & $\sqrt{ }$ & & $\sqrt{ }$ \\
\hline Asn142 & & $3,10^{*}$ & $\sqrt{ }$ & & $\sqrt{ }$ & $\sqrt{ }$ & $\sqrt{ }$ & $\sqrt{ }$ & & $\sqrt{ }$ & & $3,07^{\star}$ & $\sqrt{ }$ & \\
\hline Gly143 & $\sqrt{ }$ & $\sqrt{ }$ & $3,11^{*}$ & & $2,96^{*}$ & $\sqrt{ }$ & $\sqrt{ }$ & & & $\sqrt{ }$ & & $3,03^{*}$ & $\sqrt{ }$ & \\
\hline Ser144 & & & $\sqrt{ }$ & & $3,07^{\star}$ & $\sqrt{ }$ & & & & & & $2,90^{*}$ & & \\
\hline Cys 145 & & & $3,24^{*}$ & $\sqrt{ }$ & $3,31^{*}$ & $\sqrt{ }$ & $\sqrt{ }$ & $\sqrt{ }$ & & $\sqrt{ }$ & & $3,17^{*}$ & $\sqrt{ }$ & \\
\hline His163 & $\sqrt{ }$ & $\sqrt{ }$ & $\sqrt{ }$ & $\sqrt{ }$ & $\sqrt{ }$ & & & $3,02^{*}$ & & $\sqrt{ }$ & & $\sqrt{ }$ & $\sqrt{ }$ & $\sqrt{ }$ \\
\hline His164 & & & $\sqrt{ }$ & & & $\sqrt{ }$ & $\sqrt{ }$ & & $\sqrt{ }$ & & & & $\sqrt{ }$ & $\sqrt{ }$ \\
\hline Met165 & $\sqrt{ }$ & $\sqrt{ }$ & $\sqrt{ }$ & & $\sqrt{ }$ & $\sqrt{ }$ & $\sqrt{ }$ & $\sqrt{ }$ & $\sqrt{ }$ & $\sqrt{ }$ & $\sqrt{ }$ & $\sqrt{ }$ & $\sqrt{ }$ & $\sqrt{ }$ \\
\hline Glu166 & $\sqrt{ }$ & $\sqrt{ }$ & & $\sqrt{ }$ & $\sqrt{ }$ & $\sqrt{ }$ & & $\sqrt{ }$ & $\sqrt{ }$ & $\sqrt{ }$ & $\sqrt{ }$ & $\sqrt{ }$ & & $3,13^{*}$ \\
\hline Leu167 & $\sqrt{ }$ & & & & & & & & & & & & & \\
\hline Pro168 & $\sqrt{ }$ & $\sqrt{ }$ & & & & & & & & & $\sqrt{ }$ & & & \\
\hline His172 & & & & & & & & & & $\sqrt{ }$ & & & & \\
\hline Asp187 & $\sqrt{ }$ & & $\sqrt{ }$ & $\sqrt{ }$ & $\sqrt{ }$ & & & & $\sqrt{ }$ & & & & & $\sqrt{ }$ \\
\hline Arg188 & $\sqrt{ }$ & $\sqrt{ }$ & $\sqrt{ }$ & & $3,10^{*}$ & & & & $\sqrt{ }$ & & & & & $\sqrt{ }$ \\
\hline Gln189 & $2,99^{*}$ & $2,96^{*}$ & $\sqrt{ }$ & $\sqrt{ }$ & $\sqrt{ }$ & & & $\sqrt{ }$ & $\sqrt{ }$ & $\sqrt{ }$ & $\sqrt{ }$ & $\sqrt{ }$ & $\sqrt{ }$ & $\sqrt{ }$ \\
\hline Thr190 & $\sqrt{ }$ & $\sqrt{ }$ & & & & & & & & & & & & \\
\hline Gln192 & $\sqrt{ }$ & $\sqrt{ }$ & & & & & & & & & & & & \\
\hline
\end{tabular}

${ }^{*}=$ jarak ikatan hidrogen, LPN = Lopinavir, RTN = Ritonavir, $15=$ Turmerone A, $18=$ Turmerone Q, $76=$ Dehydro-6-gingerdione, $82=$ Dehydrocurdione, $85=$ Curcumanolide A, 86 = Curcumanolide B, $99=15$-Hydroxyprocurcumenol, $101=($ E)-Labda-8(17),12-

1 B I M F I Volume 7 No.2 / Oktober 2020 - Desember 2020 
diene-15,16-dial, 137 = Curcuminol D, $165=4$-oxo- $\beta$-isodamascol, 184 = zerumbone epoxide, 212 = thyl 4-methoxy-transcinnamate

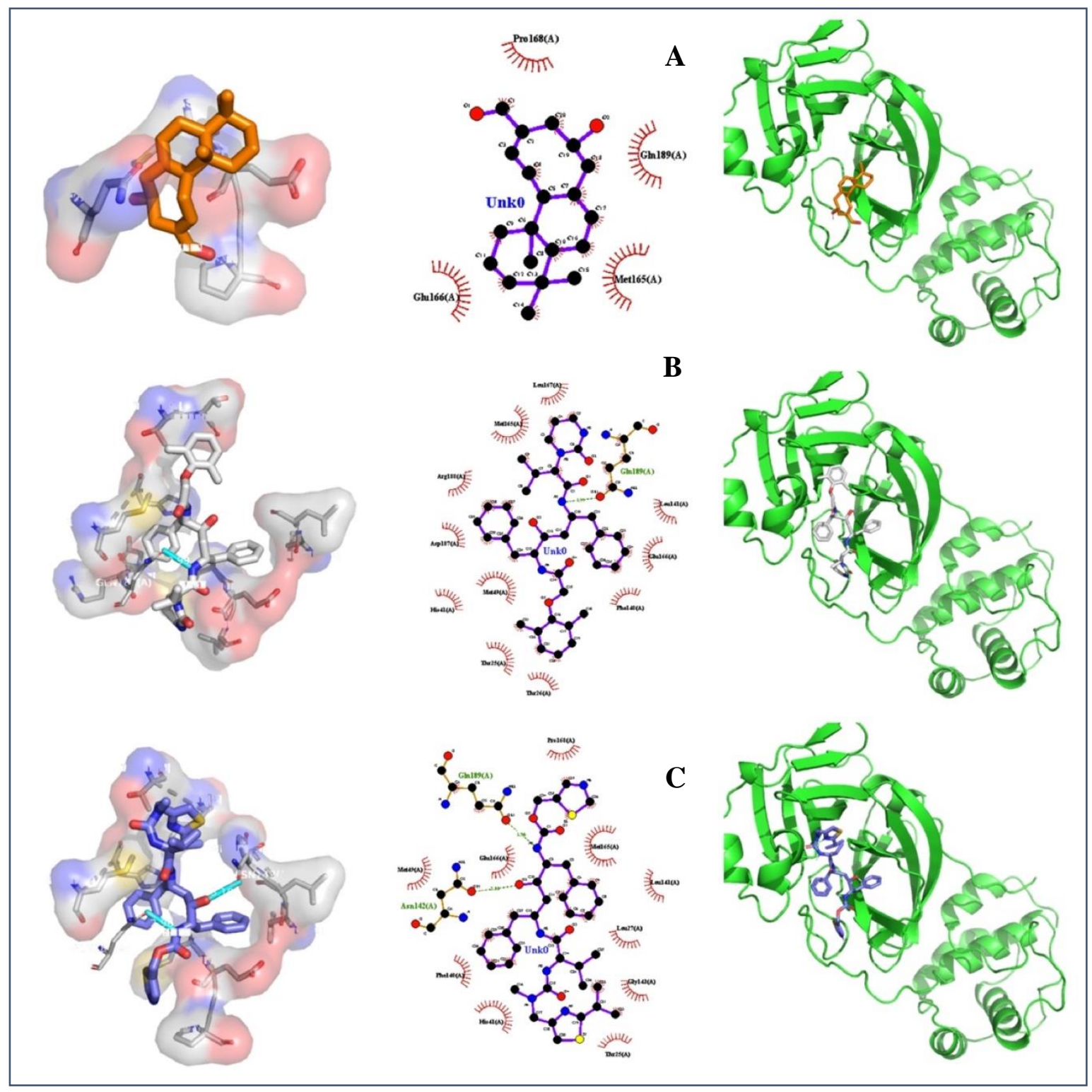

Gambar 2. Visualisasi 2D dan 3D dari (A) Curcuminol D, (B) Lopinavir, dan (C) Ritonavir Menggunakan Program Ligplot+ dan PyMOL

4. PEMBAHASAN

\subsection{Penapisan Berdasarkan Prediksi} ADMET terhadap Senyawa Bioaktif dari Jamu

Penapisan berdasarkan prediksi ADMET dan Lipinski's Rule of Five menghasilkan 12 senyawa yang memenuhi kriteria (Tabel 1).

Berdasarkan hasil prediksi, 12 senyawa ini memiliki tingkat absorbsi tinggi di saluran cerna, skor bioavailabilitas 0,55, diklasifikasikan ke dalam kelas VI LD50 (konsentrasi lebih dari $5.000 \mathrm{mg} / \mathrm{kg}$ ), non-karsinogenik, non-mutagenik, 
memiliki $<5$ donor ikatan hidrogen (kisaran 0-2), memiliki <10 akseptor ikatan hidrogen (kisaran 2-4), memiliki $<500$ Da massa molekul (kisaran 206,24$302,45 \mathrm{Da}$ ) dan $<5$ log $\mathrm{P}$ (kisaran 1,89$4,25)$ sehingga dinyatakan memenuhi kriteria penapisan.

Profil farmakokinetik sangat penting untuk memastikan senyawa dapat mengikat reseptor target di dalam tubuh dan telah dibuktikan bahwa prediksi ADME pada tahap awal proses penemuan obat baru dapat mengurangi tingkat kegagalan terkait farmakokinetik pada fase berikutnya (Daina, Michielin, \& Zoete, 2017). Prediksi ADME oleh SwissADME yang dilakukan dalam penelitian ini meliputi prediksi absorpsi melalui difusi pasif saluran gastrointestinal manusia (Daina, Michielin, \& Zoete, 2017) dan skor bioavailabilitas yang dapat diartikan sebagai probabilitas bahwa suatu senyawa akan memiliki $>10 \%$ bioavailabilitas pada tikus atau permeabilitas pada Caco-2 (Martin, 2005).

Keamanan suatu obat juga menjadi faktor penting yang harus diperhatikan dalam pengembangan obat, terutama yang berkaitan dengan toksisitas obat dan efek sampingnya (Yang, Sun, Li, Liu, \& Tang, 2018). Salah satu metode yang cepat dan hemat biaya untuk memprediksi toksisitas obat adalah menggunakan metode in silico berbasis machine-learning seperti ProTox-II (Banerjee, Eckert, Schrey \& Preissner, 2018; Myatt et al., 2018). Prediksi toksisitas menggunakan ProTox-Il yang dilakukan pada penelitian ini meliputi prediksi nilai LD50, prediksi karsinogenisitas dan mutagenisitas. Perkiraan nilai LD50 adalah prediksi median dosis letal (mg/kgBB) yang didasarkan pada kemiripan rata-rata dengan tiga senyawa toksik paling mirip dari dataset dengan nilai toksisitas oral hewan pengerat yang telah diketahui. Prediksi karsinogenisitas melibatkan data dari Carcinogenic Potency Database (CPDB) dan Chemical Effects in Biological Systems (CEBS). Sedangkan prediksi mutagenisitas didasarkan pada kumpulan data dari uji Ames dan pangkalan data CEBS (Banerjee, Eckert, Schrey \& Preissner, 2018).

Seiring dengan prediksi ADMET, kami memasukkan Lipinski's Rule of Five sebagai parameter penapisan untuk mengevaluasi drug-likeness dan untuk menentukan apakah suatu senyawa memiliki fitur kimia dan fisik yang mirip dengan obat yang dapat dikonsumsi secara oral oleh manusia (Lipinski, 2004). Parameter tersebut penting untuk diperhatikan dalam pengembangan obat karena penapisan awal senyawa dengan parameter tersebut dapat meningkatkan keefektifan proses penemuan obat karena menghilangkan masalah terkait struktur yang berkaitan dengan profil farmakokinetik dan toksisitas senyawa sejak tahap awal penemuan obat. 


\subsection{Penambatan Molekuler dan Analisis Senyawa Hasil \\ Penapisan}

Setelah didapatkan 12 senyawa yang memenuhi kriteria parameter ADMET dan Lipinski's Rule of Five, dilakukan penambatan molekuler untuk melihat afinitas pengikatan antara ligan dan makromolekul Mpro SARS-CoV-2. Penambatan dilakukan dengan parameter tervalidasi yang memiliki nilai RMSD terendah. Nilai RMSD dinilai dari hasil superposisi native ligand dan hasil redocking (Tabel 2).

Dari hasil validasi, parameter dengan nilai exhaustiveness 8 dan ukuran grid box $26,25 \AA$ memenuhi kriteria RMSD, yaitu bernilai di bawah 2 Å. Gambar superposisi native ligand dan hasil redocking validasi dapat dilihat pada Gambar 1. RMSD dibawah $2 \AA$ menunjukkan bahwa hasil penambatan dapat diterima dan sesuai (Berry, Fielding, \& Gamieldien, 2015; CastroAlvarez, Costa \& Vilarrasa, 2017). Perhitungan RMSD bertujuan untuk melihat apakah metode yang digunakan secara komputasi dapat direplikasi untuk prosedur eksperimental (Lim, Rahman, \& Tejo, 2011; Kroemer, 2007). Setelah parameter hasil validasi yang paling sesuai diperoleh, dilakukan penambatan molekuler terhadap 12 senyawa hasil penapisan ADMET terhadap protein target.

Penambatan molekuler dilakukan dengan ligan uji berupa 12 senyawa hasil penapisan serta Ritonavir dan Lopinavir sebagai kontrol positif. Ritonavir dan Lopinavir merupakan obat antiretroviral untuk pasien AIDS dengan target enzim protease HIV (Valentin, 2020). Kombinasi Ritonavir dan Lopinavir digunakan pada penyakit SARS pada 2002 dan MERS pada 2012. Beberapa penelitian mengatakan kombinasi Ritonavir-Lopinavir dapat menghambat

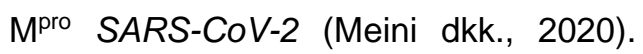
Selain itu, Ritonavir dan Lopinavir bersama dengan obat Nelfinavir, Ketoamide, dan Remdesivir berinteraksi dengan situs pengikatan Mpro SARSCoV-2 (Mothay \& Ramesh, 2020). Dari hasil penelitian sebelumnya, Ritonavir dan Lopinavir dianggap memberikan hasil terbaik sebagai kontrol positif dalam penghambatan $\mathrm{M}^{\text {pro }}$ SARS-CoV-2. Hasil penambatan molekul seluruh ligan uji dapat dilihat pada Tabel 3.

Analisis hasil penambatan molekuler dilakukan dengan pengamatan terhadap nilai energi bebas $(\Delta \mathrm{G})$ dan konstanta penghambatan (Ki) dari hasil penambatan molekuler. Nilai $\Delta G$ dengan angka yang kecil atau minus menunjukkan adanya kemungkinan terbentuknya ikatan antara ligan dan makromolekul (Dos Santos, Ferreira, \& Andricopulo, 2018). Nilai Ki menunjukkan konsentrasi yang dibutuhkan untuk menghasilkan setengah dari nilai penghambatan maksimum. Semakin kecil nilai Ki, semakin kuat afinitas ligan terhadap makromolekul (Vargas, Lopez, Piñol, \& Froeyen, 2018). 
Dari hasil penambatan molekuler pada Tabel 3, dapat dilihat tiga senyawa dengan nilai $\Delta G$ dan $K i$ terendah, yaitu Curcuminol D (Senyawa 137) dengan nilai $\Delta \mathrm{G}-6,9 \mathrm{kkal} / \mathrm{mol}$ dan $\mathrm{Ki} 2,99 \mu \mathrm{M}$, Turmerone A (Senyawa 15) dengan nilai $\Delta \mathrm{G}-6,3 \mathrm{kkal} / \mathrm{mol}$ dan $\mathrm{Ki}$ 9,04 $\mu \mathrm{M}$ serta Turmerone $\mathrm{Q}$ (Senyawa 18 ) dengan nilai $\Delta \mathrm{G}-6,2 \mathrm{kkal} / \mathrm{mol}$ dan $\mathrm{Ki}$ 10,87 $\mu \mathrm{M}$. Turmerone A dan Turmerone $Q$ memiliki struktur yang serupa, hanya memiliki perbedaan proyeksi $-\mathrm{OH}$ dan $\mathrm{H}$ pada bagian heksana. Pada senyawa Curcumanolide A (Senyawa 85) dan Curcumanolide B (Senyawa 86) yang hanya berbeda dari atom $O$ pada bagian pentana, terdapat selisih $-0,3 \mathrm{kkal} / \mathrm{mol}$ pada nilai $\Delta$ G-nya $(-5,8 \mathrm{kkal} / \mathrm{mol}$ dan $-5,5$ $\mathrm{kkal} / \mathrm{mol}$ ). Hal tersebut mengartikan bahwa perbedaan proyeksi kimiawi dapat mempengaruhi nilai $\Delta \mathrm{G}$ ligan.

Jika dibandingkan dengan kontrol positif, tidak ada senyawa ligan uji dari jamu yang memiliki nilai $\Delta G$ lebih rendah. Ritonavir dan Lopinavir memiliki nilai $\Delta \mathrm{G}-7,8 \mathrm{kkal} / \mathrm{mol}$ dan $-8,2 \mathrm{kkal} / \mathrm{mol}$ dan nilai $\mathrm{Ki}$ 0,71 $\mu \mathrm{M}$ dan 0,27 $\mu \mathrm{M}$. Perbedaan nilai $\Delta G$ dari Curcuminol $D$ dengan Ritonavir dan Lopinavir adalah $0,9 \mathrm{kkal} / \mathrm{mol}$ dan $-1,3 \mathrm{kkal} / \mathrm{mol}$. Hal ini menunjukkan bahwa senyawa yang diuji masih memerlukan modifikasi dan optimalisasi struktur untuk mendapatkan hasil yang lebih potensial. Selain itu, perluasan parameter ADMET dapat dilakukan sehingga lebih banyak senyawa yang dapat diuji terhadap $\mathrm{M}^{\text {pro }}$ SARS-CoV-2.
Selanjutnya, dilakukan pengamatan visualisasi $2 \mathrm{D}$ dan $3 \mathrm{D}$ dari kompleks ligan dan makromolekul untuk menentukan asam amino mana yang berperan dalam penghambatan $\mathrm{M}^{\text {pro }}$ SARS-CoV-2. Hasil visualisasi dapat dilihat pada Tabel 4. Visualisasi lengkap Ritonavir, Lopinavir, dan Curcuminol D dapat dilihat pada Gambar 2. Beberapa penelitian lain juga menunjukkan residu asam amino yang serupa dengan hasil penambatan Ritonavir dan Lopinavir. Interaksi Lopinavir dengan His41, Met49, Phe140, Leu141, His163, Met165, Glu166, Leu167, Pro168, Arg188, Gln189, Thr190, dan GIn192 Mpro SARSCoV-2 juga disebutkan oleh Khaerunnisa dkk pada tahun 2020 (Khaerunnisa, Kurniawan, Awaluddin, \& Suhartati, 2020). Selain itu, interaksi Ritonavir dengan His41, Asn142, Met165, Glu166, Pro168, dan Gln189 Mpro SARS-CoV-2 ditemukan oleh Muralidharan dkk pada tahun 2020 (Muralidharan, Sakthivel, Velmurugan, \& Gromiha, 2020).

Berdasarkan hasil visualisasi yang telah dilakukan, tidak ada asam amino yang berinteraksi dengan seluruh ligan. Met165 merupakan asam amino yang memiliki interaksi paling banyak dengan ligan uji, yaitu sebanyak 13 ligan uji yang berinteraksi dengan Met165. Oleh karena itu, tidak dapat disimpulkan dengan pasti asam amino mana yang berperan sebagai tempat pengikatan utama pada protein. Gln189 membentuk ikatan hidrogen dengan Ritonavir dan Lopinavir dan juga berinteraksi dengan 
sebagian besar ligan uji sehingga perannya dalam penghambatan $M^{\text {pro }}$ SARS-CoV-2 dapat diteliti lebih lanjut. Curcuminol $D$ yang hanya berinteraksi dengan Met165, Glu166, Pro168, dan GIn189 dapat menghasilkan nilai $\Delta G$ yang lebih rendah dibandingkan senyawa uji lainnya. Keempat peran asam amino tersebut juga berikatan dengan Ritonavir dan Lopinavir sehingga fungsinya sebagai tempat katalitik dapat dipelajari lebih lanjut.

Dehydro-6-gingerdione

(Senyawa 76) and 4-oxo- $\beta$-isodamascol (Senyawa 165) membentuk banyak ikatan hidrogen tetapi tidak memiliki $\Delta G$ yang lebih rendah dari Curcuminol D. Berdasarkan visualisasi interaksi ligan dengan makromolekul, terdapat kemungkinan terhambatnya $\mathrm{M}^{\text {pro }}$ SARSCoV-2 dipengaruhi oleh sifat sterik struktur ligan uji. Hal ini ditunjukkan dengan Curcuminol $D$ yang lebih sterik tetapi kurang elektrofilik yang memiliki nilai $\Delta \mathrm{G}$ yang lebih rendah dibandingkan dengan ligan uji lainnya. Hal ini juga didukung oleh bukti bahwa Ritonavir dan Lopinavir memiliki struktur sterik dibandingkan ligan lainnya.

\section{KESIMPULAN}

COVID-19 saat ini merupakan pandemi yang pertama kali muncul di Wuhan, China, dan menyebar ke seluruh dunia. Meski demikian, masih belum ada terapi anti-COVID-19 yang spesifik dan terapi antivirus yang efektif masih kurang. Oleh karena itu, senyawa kimia dalam jamu yang diketahui memiliki aktivitas antivirus dapat menjadi terapi antivirus yang potensial untuk COVID19. Hasil penelitian ini menunjukkan bahwa Curcuminol $\mathrm{D}$ memiliki $\Delta \mathrm{G}$ dan $\mathrm{Ki}$ terendah $(-6,9 \mathrm{kkal} / \mathrm{mol}$ dan 2,99 $\mu \mathrm{M})$ terhadap $\mathrm{M}^{\text {pro }}$ SARS-CoV-2 diantara semua ligan uji, meskipun $\Delta \mathrm{G}$ dan Ki-nya lebih tinggi daripada yang dimiliki Lopinavir dan Ritonavir. Namun, 271 senyawa lain yang belum diketahui potensinya dapat diteliti lebih jauh.

\section{SARAN}

Diperlukan penelitian lebih lanjut mengenai potensi Curcuminol D sebagai inhibitor $M^{\text {pro }}$ SARS-CoV-2 seperti studi simulasi dinamika molekuler, studi in vitro ataupun studi in vivo serta diperlukan penelitian lebih lanjut untuk mengetahui potensi senyawa alami untuk mengobati COVID-19. Studi ini merupakan titik awal dari proses penemuan obat dari senyawa alami untuk mengobati COVID-19.

\section{UCAPAN TERIMA KASIH}

Terima kasih kepada lbu apt. Widya Dwi Aryati, M.Si. atas bimbingannya dan kepada Fakultas Farmasi Universitas Indonesia yang telah mendukung penelitian ini.

\section{DAFTAR PUSTAKA}

Ahmad, S., Abbasi, H. W., Shahid, S., Gul, S., \& Abbasi, S. W. (2020). Molecular docking, simulation and MM-PBSA studies of nigella sativa compounds: a computational quest 
to identify potential natural antiviral for COVID-19 treatment. Journal of biomolecular structure \& dynamics, $0(0)$,

https://doi.org/10.1080/07391102.20 20.1775129

Alanagreh, L., Alzoughool, F., \& Atoum, M. (2020). The Human Coronavirus Disease COVID-19: Its Origin, Characteristic, and Insights into Potential Drugs and Its Mechanism. Pathogens, 331. https://doi.org/10.3390/pathogens 90 50331

Ang, L., Lee, H. W., Choi, J. Y., Zhang, J., \& Lee, M. S. (2020). Herbal medicine and pattern identification for treating COVID-19: a rapid review of guidelines. Integrative Medicine Research, 9(2), 100407. https://doi.org/10.1016/j.imr.2020.10 0407

Banerjee, P., Eckert, A. O., Schrey, A. K., \& Preissner, R. (2018). ProTox-II: a webserver for the prediction of toxicity of chemicals. Nucleic acids research, 46(W1), W257-W263. https://doi.org/10.1093/nar/gky318

Berry, M., Fielding, B., \& Gamieldien, J. (2015). Practical Considerations in Virtual Screening and Molecular Docking. Emerging Trends in Computational Biology, Bioinformatics, and Systems Biology: Algorithms and Software Tools, 487502. https://doi.org/10.1016/B978-012-802508-6.00027-2
Booth, C. M., Matukas, L.M., Tomlinson, G., Rachlis, A.R., Rose, D.B.; Dwosh, H.A., Walmsley, S., Mazzulli, T., Avendano, M., Derkach, P., et al. (2003). Clinical Features and Shortterm Outcomes of 144 Patients with SARS in the Greater Toronto Area. The Journal of the American Medical Association, 289(21), 2801. https://doi.org/10.3390/molecules22 22010136

ChemAxon. (2019). MarvinSketch. Diakses dari http://www.chemaxon.com

Daina, A., Michielin, O., \& Zoete, V. (2017). SwissADME: A free web tool to evaluate pharmacokinetics, druglikeness and medicinal chemistry friendliness of small molecules. Scientific Reports, 7, 42717. https://doi.org/10.1038/srep42717

Dar, A. M., \& Mir, S. (2017). Molecular Docking: Approaches, Types, Applications and Basic Challenges. Journal of Analytical \& Bioanalytical Techniques, $\quad 8, \quad 356$. https://doi.org/10.4172/21559872.1000356

DeLano, W. L. (2002). The PyMOL Molecular Graphics System. DeLano Scientific, San Carlos, CA. dos Santos, R. N., Ferreira, L. G., \& Andricopulo, A. D. (2018). Practices in molecular docking and structurebased virtual screening. Methods in Molecular Biology, 1762, 31-50. https://doi.org/10.1007/978-1-4939-

7756-7_3 
Elfahmi, Woerdenbag, H. J., \& Kayser, O.

(2014). Jamu: Indonesian traditional herbal medicine towards rational phytopharmacological use. Journal of Herbal Medicine, 4(2), 51-73. https://doi.org/10.1016/j.hermed.201 4.01 .002

Estrada, E. (2020). Topological analysis of SARS CoV-2 main protease. Chaos, $\quad 30, \quad 061102$. https://doi.org/10.1063/5.0013029

Eynde, J. J. V. (2020). COVID-19: A Brief Overview of the Discovery Clinical Trial. MDPI Pharmaceuticals, 13, 65. https://doi.org/10.3390/ph13040065

Ferreira, L. G., Dos Santos, R. N., Oliva, G., \& Andricopulo, A. D. (2015). Molecular Docking and StructureBased Drug Design Strategies. Molecules, 20(7), 13384-13421. https://doi.org/10.3390/molecules20 0713384

Forero, J. E., Avila, L., Taborda, N., Tabares, P., Lopez, A., Torres, F., Quinones, W., Bucio, M. A., MoraPerez, Y., Rugeles, M. T., JosephNathan, P., Echeverri, F. (2008). In vitro anti-influenza screening of several Euphorbiaceae species: Structure of a bioactive Cyanoglucoside from Codiaeum variegatum. Phytochemistry, 69(16), 2815-2819.

https://doi.org/10.1016/j.phytochem. 2008.09.003

Frediansyah, A., Tiwari, R., Sharun, K., Dhama, K., \& Harapan, H. (2020). Clinical Epidemiology and Global
Health: Antiviral for COVID-19: A Critical Review. Clinical Epidemiology and Global Health. https://doi.org/10.1016/j.cegh.2020.0 7.006

Hall, D. C. Jr., \& Ji, H. F. (2020). A search for medications to treat COVID-19 via in silico molecular docking models of the SARS-CoV-2 spike glycoprotein and $3 \mathrm{CL}$ protease. Travel medicine and infectious disease, $\quad 35, \quad 101646$. https://doi.org/10.1016/j.tmaid.2020. 101646

Jin, Z., Du, X., Xu, Y., Deng, Y., Liu, M., Zhao, Y., \& Yang, H. (2020). Structure of Mpro from SARS-CoV-2 and discovery of its inhibitors. Nature, 582, 289-293. https://doi.org/10.1038/s41586-0202223-y

Jomah, S., Asdaq, S. M. B., Al-Yamani, M. J. (2020). Clinical Efficacy of Antivirals Against Novel Coronavirus (COVID-19): A Review. Elsevier Journal of Infection and Public Health, 13(9), 1187-1195. https://doi.org/10.1016/j.jph.2020.07 .013

Kartini, K., Jayani, N. I. E., Octaviyanti, N. D., Krisnawan, A. H., \& Avanti, C. (2019). Standardization of Some Indonesian Medicinal Plants Used in "Scientific Jamu". IOP Conference Series: Earth and Environmental Science, $\quad 391, \quad 012042$. https://doi.org/10.1088/17551315/391/1/012042 


\section{Kementerian Kesehatan Republik Indonesia. (2020). Pedoman Pencegahan dan Pengendalian Coronavirus Disease (COVID-19). Kementerian Kesehatan Republik Indonesia.}

Khaerunnisa, S., Kurniawan, H., Awaluddin, R., \& Suhartati, S. (2020). Potential Inhibitor of COVID19 Main Protease (Mpro) from Several Medicinal Plant Compounds by Molecular Docking Study. Preprints.

https://doi.org/10.20944/preprints20 2003.0226.v1

Kroemer, R. T. (2007). Structure-Based

Drug Design: Docking and Scoring. Current Protein \& Peptide Science, 8(4),312.

https://doi.org/10.2174/1389203077 81369382

Laskowski R A, \& Swindells M B (2011). LigPlot+: multiple ligand-protein interaction diagrams for drug discovery. J. Chem. Inf. Model., 51, 2778-2786.

https://doi.org/10.1021/ci200227u Li, Y., Xie, Z., Lin, W., Cai, W., Wen, C., Guan, Y., Mo, X., Wang, J., Wang, Y., Peng, P., Chen, X., Hong, W., Xiao, G., Liu, J., Zhang, L., Hu, F., Li, F., Zhang, F., Deng, X., \& Li, L. (2020). Efficacy and Safety of Lopinavir/Ritonavir or Arbidol in Adult Patients with Mild/Moderate COVID19: An Exploratory Randomized Controlled Trial. Med Clinical Advances. https://doi.org/10.1016/j.medj.2020.0 4.001

Lim, S. V., Rahman, M. B. A., \& Tejo, B. A. (2011). Structure-based and ligand-based virtual screening of novel methyltransferase inhibitors of the dengue virus. $B M C$ Bioinformatics, 12(SUPPL. 13). https://doi.org/10.1186/1471-210512-S13-S24

Lipinski CA (2004). Lead- and drug-like compounds: the rule-of-five revolution. Drug Discovery Today: Technologies. 1 (4), 337-341. https://doi.org/10.1016/j.ddtec.2004. 11.007. PMID 24981612.

Liu Y-Ya, Feng X-Yan, Jia W-Qing, Jing $Z$, Xu W-Ren, \& Cheng X-Chao. (2019). Identification of novel PI3K inhibitors by docking, ADMET prediction and molecular dynamics simulations, Computational Biology and Chemistry, 78, 190-204. https://doi.org/10.1016/j.compbiolch em.2018.12.002

Martin, Y. C. (2005). A Bioavailability Score. J. Med. Chem, 48, 31643170.

https://doi.org/10.1021/jm0492002

Meini, S., Pagotto, A., Longo, B., Vendramin, I., Pecori, D., \& Tascini, C. (2020). Role of Lopinavir/Ritonavir in the Treatment of Covid-19: A Review of Current Evidence, Guideline Recommendations, and Perspectives. Journal of Clinical Medicine, 2050. https://doi.org/10.3390/jcm9072050 
Michele, C. A., Teresa, M., Pasquale, D.

L., Matteo, C., Michele, D. P., Giovanni, M., \& Angelo, B. (2020). Pharmacological Approach and Therapeutic Options for SARS-CoV2 Infection. World of Journal of Advanced Research and Reviews, 6(1), 105-119. https://doi.org/10.30574/wjarr.2020. 6.1.0089

Moroy, G., Martiny, V. Y., Vayer, P., Villoutreix, B. O., \& Miteva, M. A. (2012). Toward in silico structurebased ADMET prediction in drug discovery. Drug Discovery Today, 17, 1-2, 44-55. https://doi.org/10.1016/j.drudis.2011. 10.023

Mothay, D., \& Ramesh, K. V. (2020). Binding site analysis of potential protease inhibitors of COVID-19 using AutoDock. VirusDisease, 31(2), 194-199. https://doi.org/10.1007/s13337-02000585-z

Muralidharan, N., Sakthivel, R., Velmurugan, D., \& Gromiha, M. M. (2020). Computational studies of drug repurposing and synergism of lopinavir, oseltamivir and ritonavir binding with SARS-CoV-2 protease against COVID-19. Journal of Biomolecular Structure and Dynamics, $\quad 0(0), \quad 1-6$. https://doi.org/10.1080/07391102.20 20.1752802

Myatt, G. J., Ahlberg, E., Akahori, Y., Allen, D., Amberg, A., Anger, L. T., Aptula, A., Auerbach, S., Beilke, L.,
Bellion, P., Benigni, R., Bercu, J., Booth, E. D., Bower, D., Brigo, A., Burden, N., Cammerer, Z., Cronin, M. T. D., Cross, K. P., \& Hasselgren, C. (2018). In silico toxicology protocols. Regulatory Toxicology and Pharmacology, 96, 1-17. https://doi.org/10.1016/j.yrtph.2018. 04.014

O’Boyle, N. M., Banck, M., James, C. A., Morley, C., Vandermeersch, T., \& Hutchison, G. R. (2011). Open Babel: An Open chemical toolbox. Journal of Cheminformatics, 3(10), 33. https://doi.org/10.1186/17582946-3-33

Otake, T., Mori, H., Morimoto, M., Ueba, N., Sutardjo, S., Kusumoto, I.T., Hattori, M., \& Namba, T. (1995). Screening of Indonesian plantextracts for anti-humanimmunodeficiency-virus type-1 (HIV1) activity. Phytotherapy research, 9, 6-10.

https://doi.org/10.1002/ptr.26500901 03

Principi, N., \& Esposito, S. (2020). Chloroquine or Hydroxychloroquine for Prophylaxis of COVID-19. The Lancet, 20(10), 1118. https://doi.org/10.1016/S14733099(20)30296-6

Qamar, M. T., Alqahtani, S. M., Alamri, M. A., \& Chen, L. (2020). S tructural basis of SARS-CoV-2 3CLpro and anti-COVID-19 drug discovery from medicinal plants. Journal of Pharmaceutical Analysis, 10(4), 
313-319.

https://doi.org/10.1016/j.jpha.2020.0 3.009

Sirisha, N., Sreenivasulu, M., Sangeeta, K., \& Chetty, C. M. (2010). Antioxidant properties of Ficus Species - a review. International Journal of PharmTech Research, 2(4), 2174-2182.

Tan, E. L. C., Ooi, E. E., Lin, C. Y., Tan, H. C., Ling A. E., Lim, B., \& Stanson L. W. (2004). Inhibition of SARS Coronavirus Infection In Vitro with Clinically Approved Antiviral Drugs. Emerging Infectious Diseases, 10(4), 581-586. https://doi.org/ 10.3201/eid1004.030458

Tan, W. C., Jaganath, I. B., Manikam, R., \& Sekaran, S. D. (2013). Evaluation of Antiviral Activities of Four Local Malaysian Phyllanthus Species against Herpes Simplex Viruses and Possible Antiviral Target. Int $\mathrm{J}$ Med Sci, 10(13), 1817-1829. https://doi.org/10.7150/ijms.6902

Torres, P., Sodero, A., Jofily, P., \& SilvaJr, F. P. (2019). Key Topics in Molecular Docking for Drug Design. International journal of molecular sciences, 20(18), 4574. https://doi.org/10.3390/ijms2018457 4

Trott, O., \& Olson, A. J. (2009). AutoDock Vina: Improving the speed and accuracy of docking with a new scoring function, efficient optimization, and multithreading. Journal of Computational Chemistry,
$31(2)$, 455-461. https://doi.org/10.1002/jcc.21334

Ulrich, S., \& Nitsche, C. (2020). The SARS-CoV-2 main protease as drug target. Bioorganic \& Medicinal Chemistry Letters, 30(17), 127377. https://doi.org/10.1016/j.bmcl.2020.1 27377

United State Food and Drug Administration. (2020). Coronavirus Treatment Acceleration Program (CTAP). Diakses pada 1 September 2020, dari https://www.fda.gov/drugs/coronavir us-covid-19-drugs/coronavirustreatment-acceleration-program-ctap Valentin, F. (2020). Lopinavir/Ritonavir and COVID-19. ResearchGate, (April).

https://doi.org/10.13140/RG.2.2.148 44.69767

Vargas, J. A. R., Lopez, A. G., Piñol, M. C., \& Froeyen, M. (2018). Molecular docking study on the interaction between 2-substituted-4,5-difuryl Imidazoles with different protein target for antileishmanial activity. Journal of Applied Pharmaceutical Science, $\quad 8(3)$, 14-22. https://doi.org/10.7324/JAPS.2018.8 303

Wahyuni, T. S., Azmi, D., Permanasari, A. A., Adianti, M., Tumewu, L., Widiandani, T., Utsubo, C. A., Widyawaruyanti, A., Fuad, A., \& Hotta, H. (2019). Anti-viral activity of Phyllanthus niruri against hepatitis C virus. Malaysian Applied Biology, 48(3): 105-111. 
Widyowati, R., \& Agil, M. (2018). Chemical Constituents and Bioactivities of Several Indonesian Plants Typically Used in Jamu. Chemical \& pharmaceutical bulletin, 66(5), 506-518. https://doi.org/10.1248/cpb.c1700983

Worldometer. (2020). Coronavirus Update (Live): 25,386,928 Cases and 850,592 Deaths from COVID-19 Virus Pandemic - Worldometer. Diakses pada 1 September 2020, dari

https://www.worldometers.info/coron avirus/

World Health Organization. (2020). COVID-19 Strategy Update. World Health Organization.

World Health Organization. (2020). "Solidarity" Clinical Trial for COVID19 Treatments. Diakses pada 1 September 2020, dari https://www.who.int/emergencies/dis eases/novel-coronavirus2019/global-research-on-novelcoronavirus-2019-ncov/solidarityclinical-trial-for-covid-19-treatments

Yang, H., Sun, L., Li, W., Liu, G., \& Tang, Y. (2018). In Silico Prediction of Chemical Toxicity for Drug Design Using Machine Learning Methods and Structural Alerts. Frontiers in Chemistry, 6, 1-12. https://doi.org/10.3389/fchem.2018. 00030

Zhang, L., \& Liu, Y. (2020). Potential Interventions for Novel Coronavirus in China: A Systemic Review.
Journal of Medical Virology,

92(2020),

479-

490. https://doi.org/10.1002/jmv.257 07

Zheng, J. (2020). SARS-CoV-2: An Emerging Coronavirus that Causes a Global Treat. International Journal of Biological Sciences, 16(10), 16781685.

https://doi.org/10.7150/ijbs.45053

Zumla, A., Chan, J.F.W., Azhar, E.I., Hui, D.S.C., \& Yuen, K. (2016). Coronaviruses - drug discovery and therapeutic options. Nature Reviews Drug Discovery, 15, 327-347. https://doi.org/10.1038/nrd.2015.37 